\title{
Correlation between IL-28 Polymorphism and Spontaneous Clearance in HCV Patients: Systematic Review and Meta-Analysis
}

\section{Hamid Heidarian Miri}

Mashhad University of Medical Sciences

\section{Pooria Fazeli}

Shiraz University of Medical Sciences

\section{Mohammad Ali-Hassanzadeh}

Jiroft University of Medical Sciences

\section{Peyman Bemani}

Shiraz University of Medical Sciences

\section{Dieter Kabelitz}

University of Kiel

kurosh kalantar ( $\sim$ kalantark@sums.ac.ir)

Shiraz University of Medical Sciences https://orcid.org/0000-0002-9160-9449

\section{Research Article}

Keywords: Hepatitis C virus, IL28B gene, Polymorphisms, Spontaneous Clearance

Posted Date: April 12th, 2021

DOl: https://doi.org/10.21203/rs.3.rs-203303/v1

License: (a) (i) This work is licensed under a Creative Commons Attribution 4.0 International License. Read Full License 


\section{Abstract}

Hepatitis $\mathrm{C}$ virus (HCV) is a serious global health issue. Nearly $20 \%$ of HCV patients spontaneous clear the virus. While some studies have shown the association of spontaneous clearance (SC) of the virus with Interleukin (IL) 28B single nucleotide polymorphisms (SNPs), others didn't show such a relationship. Thus, the purpose of the present study was to investigate the association of IL28B polymorphisms (12979860 SNP) and SC of HCV infection. Upon initial screening of the databases, a total of 545 articles were retrieved, of which 22 studies that met predefined eligibility criteria were entered into the meta-analysis. Odds ratios (OR) with its confidence intervals $(95 \% \mathrm{Cl})$, heterogeneity, publication bias, and sensitivity analysis were assessed. According to the meta-analysis results, a significant association was observed between the rs 12979860 SNP and SC of HCV infection. The results indicated that the ORs of SC from hepatitis $\mathrm{C}$ virus infection were 2.75 times higher in those with cytokine gene polymorphisms, $95 \% \mathrm{Cl}(2.23$ to 3.38). Moreover, it was found that the prevalence of rs $12979860 \mathrm{CC}$ was 0.33 with $95 \mathrm{Cl}(0.28-0.38)$ in genotype one and was 0.40 with $95 \mathrm{Cl}(0.34-0.47)$ in other genotypes.

Our meta-analysis results suggest that IL $28 \mathrm{~B}$ rs $12979860 \mathrm{CC}$ is a strong predictor for SC of hepatitis C infection in PEG IFN-a/RBV-treated patients.

\section{Introduction}

Hepatitis C virus $(\mathrm{HCV})$ is a serious public health problem worldwide affecting $>170$ million persons globally and around 3-4 million people are newly infected each year [1-3]. Although HCV causes liver related morbidity and mortality and $>70 \%$ of patients will develop chronic HCV infection, $20 \%$ of patients show spontaneous clearance (SC) of the viral infection [4,5]. While the pathogenicity of HCV has not been completely determined, studies have shown that several viral and host factors have been connected to the differences in the viral persistence or clearance. Also, HCV patients respond differently to the treatment, indicating an important role of the host genetic context [6-8]. Several studies have shown that SC of virus and response to treatment might be related to interleukin (IL) 28B gene polymorphisms. There are three main single nucleotide polymorphisms (SNPs) for the IL28B gene including rs12979860, rs809917, and rs12980275. Several studies showed that there is a correlation between these SNPs and SC, treatment, and prediction of response $[9,4,10]$. Because these SNPs are located in the promoter and regulatory region of the IL28B gene on chromosome 19, they can affect IL28B cytokine gene expression and production. Besides, SC of HCV infections may be affected by these SNPs $[7,11]$.

The antiviral properties of IL28B protein are mediated by stimulating the Janus kinase signal transducer and activator of transcription (JAK-STAT) protein, which controls interferon (IFN)-stimulated genes (ISGs) [12]. Many publications have reported the influence of IL28B polymorphisms on the clearance of HCV. one study conducted on the Asian population, patients with CC genotype at the rs 12079860 SNP showed spontaneous clearance [13]. Furthermore, patients with rs12979860 SNP were associated with IFN-free treatment [14-16]. Besides, it has been shown that the C/C genotype at rs 12979860 of IL28B is associated with sustained virologic response (SVR) in Asian, Caucasian, European, African-American and Hispanic populations $[17,4]$. To date, various meta-analyses have been released on the correlation between gene 
polymorphisms of IL28B and SVR [17-21] but, few meta-analyses have been performed on the IL28B polymorphisms that are involved in SC. Furthermore, the studies have reached inconsistent conclusions and while some studies reported a significant association [22-39,19,40-42], some others didn't show such relation $[43,44]$. Accordingly, the objective of this paper was to clarify the association of IL28B polymorphisms with pegylated interferon (IFN) a and ribavirin (RBV) (PEG-IFN/RBV) treatment response and SC.

\section{Methods}

The present systematic review and meta-analysis was accomplished based on the Preferred Reporting Items for Systematic Reviews and Meta-Analysis (PRISMA) statement. (http://www.prisma statement.org/PRISMAStatement/ PISMAStatement.aspx).

\section{Search strategy and data extraction}

We identified relevant publications through a comprehensive and systematic search of databases of PubMed, MEDLINE/PubMed, Web of Science Scopus, and Google Scholar using keywords rs 12979860, IL -28 gene, Interferon lambda-3, Polymorphism, HCV, Spontaneous clearance, spontaneous resolution, spontaneous recovery (SR) and chronic hepatitis C. "AND" and "OR" Boolean operators were used for combining search keywords in the above-mentioned databases. The included papers were, first, screened based on their title, abstract, and keywords to select the eligible ones. Next, the full texts of the selected papers were evaluated by two independent reviewers. In the case of disagreement, the reviewers discussed until a consensus was reached. Through searching various databases, 545 articles were identified. Out of these, 515 were removed because they were irrelevant or duplicate articles. Then, the remaining 30 studies were assessed according to the title and abstract, and two publications did not qualify for assessing the full-text. Next, the full-text of the 28 eligible articles was evaluated of which, 6 papers were removed because of irrelevant and incomplete results, and finally, 22 studies were included in the meta-analysis (Fig. 1). Full or Entire searches were limited to English-language articles published between April 2011 and November 2019. The PRISMA flow diagram (http://prismastatement.org/PRISMAStatement/FlowDiagram.aspx) illustrates the process of selection of included studies (Fig. 1).

\section{Inclusion and exclusion criteria}

Studies satisfying the below criteria were considered in our meta-analysis: 1) Case-control studies 2) published literature related to the association of cytokine gene polymorphisms (exposure) and spontaneous recovery (SR) from hepatitis $C$ virus infection (outcome), 3) All cross-sectional, randomized controlled trials, case-series and cohort studies reporting on SC in HCV patients with at least 9 patients in two compared groups, 4) The original studies must provide the number of each group and the percentage of SC in each group. The papers with incomplete and non-relevant data were not noticed in this metaanalysis.

\section{Assessment of study quality and risk of bias}


The risk of bias of studies was evaluated using the Newcastle and Ottawa checklist by the two independent reviewers. In the case of disagreement, the two reviewers were further discussed in accompany with the third reviewer until reaching consensus (Table 1). 
Table 1

Characteristics of 22 clinical trials included in study

\begin{tabular}{|c|c|c|c|c|c|c|c|}
\hline $\begin{array}{l}\text { First } \\
\text { author,Year and } \\
\text { Country }\end{array}$ & Design & $\begin{array}{l}\text { No. of } \\
\text { patient }\end{array}$ & $\begin{array}{l}\text { Gender } \\
\text { Male n(\%) }\end{array}$ & $\begin{array}{l}\mathrm{IL}-28 \\
\mathrm{SNP}(\mathrm{s})\end{array}$ & $\begin{array}{l}\text { Event } \\
\text { Exposure } \\
\text { (n) }\end{array}$ & $\begin{array}{l}\text { Non } \\
\text { Exposure } \\
\text { (n) }\end{array}$ & IDst \\
\hline $\begin{array}{l}\text { Mohamed } \\
\text { Hashem [23] } \\
2017 \text { Pakistan }\end{array}$ & Prospective & $54 \mathrm{a}$ & $0(0 \%)^{*}$ & $\begin{array}{l}\text { rs } \\
12979860\end{array}$ & $18 / 38$ & $10 / 14$ & 1 \\
\hline $\begin{array}{l}\text { Sarvari, J [23] } \\
2017 \text { Iran }\end{array}$ & $\begin{array}{l}\text { Cross- } \\
\text { sectional }\end{array}$ & 338 & $\begin{array}{l}296 \\
(87.5 \%)\end{array}$ & $\begin{array}{l}\text { rs } \\
12979860\end{array}$ & $41 / 302$ & $20 / 36$ & 2 \\
\hline $\begin{array}{l}\text { Edmondo } \\
\text { Falleti [59] } \\
2011 \text { Italy }\end{array}$ & Retrospective & 1057 & $\begin{array}{l}671 \\
(63.5 \%)\end{array}$ & $\begin{array}{l}\text { rs } \\
12979860\end{array}$ & $205 / 629$ & $201 / 428$ & 3 \\
\hline $\begin{array}{l}\text { Jason Grebely } \\
\text { [25] } 2014 \\
\text { Australia }\end{array}$ & Retrospective & 632 & 404 (64\%) & $\begin{array}{l}\text { rs } \\
12979860\end{array}$ & $168 / 459$ & $98 / 173$ & 4 \\
\hline $\begin{array}{l}\text { R Carapito [60] } \\
2015 \text { Iran }\end{array}$ & $\begin{array}{l}\text { Cross- } \\
\text { sectional }\end{array}$ & 283 & $187(66 \%)$ & $\begin{array}{l}\text { rs } \\
12979860\end{array}$ & $85 / 176$ & $69 / 107$ & 5 \\
\hline $\begin{array}{l}\text { Indolfi } \\
\text { Giuseppe [61] } \\
2014 \text { Italy }\end{array}$ & $\begin{array}{l}\text { Cross- } \\
\text { sectional }\end{array}$ & 177 & $\begin{array}{l}96 \\
(54.2 \%)\end{array}$ & $\begin{array}{l}\text { rs } \\
12979860\end{array}$ & $48 / 147$ & $17 / 30$ & 6 \\
\hline $\begin{array}{l}\text { Aldaco - } \\
\text { Gonzalez, K } \\
{[62] 2016} \\
\text { Mexico }\end{array}$ & $\begin{array}{l}\text { Cross- } \\
\text { sectional }\end{array}$ & 234 & $\begin{array}{l}90 \\
(38.4 \%)\end{array}$ & $\begin{array}{l}\text { rs } \\
12979860\end{array}$ & $35 / 149$ & $39 / 85$ & 7 \\
\hline $\begin{array}{l}\text { Vincent } \\
\text { Pedergnana } \\
{[41] 2012} \\
\text { France }\end{array}$ & $\begin{array}{l}\text { Cross- } \\
\text { sectional }\end{array}$ & 261 & NR & $\begin{array}{l}\text { rs } \\
12979860\end{array}$ & NR & NR & 8 \\
\hline $\begin{array}{l}\text { Susanne Knapp } \\
\text { [63] } 2011 \text { UK }\end{array}$ & $\begin{array}{l}\text { Cross- } \\
\text { sectional }\end{array}$ & 323 & 197 (61\%) & $\begin{array}{l}\text { rs } \\
12979860\end{array}$ & $102 / 234$ & $62 / 89$ & 9 \\
\hline $\begin{array}{l}\text { Sayeh Ezzikouri } \\
\text { [29] } 2013 \\
\text { Morocco }\end{array}$ & $\begin{array}{l}\text { Cross- } \\
\text { sectional }\end{array}$ & 300 & $\begin{array}{l}79 \\
(26.3 \%)\end{array}$ & $\begin{array}{l}\text { rs } \\
12979860\end{array}$ & $89 / 232$ & $45 / 68$ & 10 \\
\hline $\begin{array}{l}\text { Indolfi } \\
\text { Giuseppe [64] } \\
2014 \text { Italy }\end{array}$ & $\begin{array}{l}\text { Cross- } \\
\text { sectional }\end{array}$ & 153 & $84(54.9 \%)$ & $\begin{array}{l}\text { rs } \\
12979860\end{array}$ & $43 / 130$ & $14 / 23$ & 11 \\
\hline $\begin{array}{l}\text { Fuat Kurbanov } \\
\text { [31] } 2011 \text { Egypt }\end{array}$ & Retrospective & 162 & $\begin{array}{l}66 \\
(40.8 \%)\end{array}$ & $\begin{array}{l}\text { rs } \\
12979860\end{array}$ & $25 / 82$ & $48 / 80$ & 12 \\
\hline
\end{tabular}

Abbreviations : HCV, hepatitis C virus; SNP, single-nucleotide polymorphism; n, number; (\%), (percentage); Event Exposure, the individuals with both chronic hepatitis C \& favorable SNP (rs 12979860 CC); Non Exposure, the individuals with both spontaneous resolution \& \& favorable SNP (rs 12979860 CC); IDst, ID study; NR, not reported; *, the whole of sample size in pregnant women; a, 2 cases of samples were missed; b, 1 case of samples was missed c, the analysis for 7 cases of samples was not applicable 


\begin{tabular}{|c|c|c|c|c|c|c|c|}
\hline $\begin{array}{l}\text { First } \\
\text { author,Year and } \\
\text { Country }\end{array}$ & Design & $\begin{array}{l}\text { No. of } \\
\text { patient }\end{array}$ & $\begin{array}{l}\text { Gender } \\
\text { Male n(\%) }\end{array}$ & $\begin{array}{l}\text { IL }-28 \\
\text { SNP (s) }\end{array}$ & $\begin{array}{l}\text { Event } \\
\text { Exposure } \\
\text { (n) }\end{array}$ & $\begin{array}{l}\text { Non } \\
\text { Exposure } \\
\text { (n) }\end{array}$ & IDst \\
\hline $\begin{array}{l}\text { Susanne Knapp } \\
\text { [65] } 2015 \text { UK }\end{array}$ & $\begin{array}{l}\text { Cross- } \\
\text { sectional }\end{array}$ & 185 & $\begin{array}{l}114 \\
(61.6 \%)\end{array}$ & $\begin{array}{l}\text { rs } \\
12979860\end{array}$ & $29 / 108$ & $44 / 77$ & 13 \\
\hline $\begin{array}{l}\text { Silva- Fabrício, } \\
\text { G.M [66] } 2015 \\
\text { Brazil }\end{array}$ & Retrospective & 286 & $\begin{array}{l}147 \\
(51.4 \%)\end{array}$ & $\begin{array}{l}\text { rs } \\
12979860\end{array}$ & $61 / 245$ & $24 / 41$ & 14 \\
\hline $\begin{array}{l}\text { Fatma M. Shebl } \\
\text { [34] } 2011 \text { USA }\end{array}$ & $\begin{array}{l}\text { Cross- } \\
\text { sectional }\end{array}$ & 1209 & $\begin{array}{l}825 \\
(68.8 \%)\end{array}$ & $\begin{array}{l}\text { rs } \\
12979860\end{array}$ & 273/883 & $182 / 326$ & 15 \\
\hline $\begin{array}{l}\text { Heidar Sharafi } \\
\text { [35] } 2014 \text { Iran }\end{array}$ & $\begin{array}{l}\text { Cross- } \\
\text { sectional }\end{array}$ & 350 & $\begin{array}{l}333 \\
(95.1 \%)\end{array}$ & $\begin{array}{l}\text { rs } \\
12979860\end{array}$ & $95 / 259$ & $64 / 91$ & 16 \\
\hline $\begin{array}{l}\text { Laird, M.E [67] } \\
2014 \text { France }\end{array}$ & $\begin{array}{l}\text { Cross- } \\
\text { sectional }\end{array}$ & 174 & $\begin{array}{l}91 \\
(52.3 \%)\end{array}$ & $\begin{array}{l}\text { rs } \\
12979860\end{array}$ & $24 / 141$ & $19 / 33$ & 17 \\
\hline $\begin{array}{l}\text { Jacob } \\
\text { Nattermann } \\
\text { [68] } 2011 \\
\text { Germany }\end{array}$ & $\begin{array}{l}\text { Cross- } \\
\text { sectional }\end{array}$ & 501 & $0(0 \%)$ * & $\begin{array}{l}\text { rs } \\
12979860\end{array}$ & $140 / 396$ & $42 / 105$ & 18 \\
\hline $\begin{array}{l}\text { Enea Spada } \\
\text { [69] } 2013 \text { Italy }\end{array}$ & $\begin{array}{l}\text { Cross- } \\
\text { sectional }\end{array}$ & 56 & $\begin{array}{l}39 \\
(69.6 \%)\end{array}$ & $\begin{array}{l}\text { rs } \\
12979860\end{array}$ & $19 / 38$ & $14 / 18$ & 19 \\
\hline $\begin{array}{l}\text { Rong-Rong Wu } \\
\text { [70] } 2014 \text { China }\end{array}$ & $\begin{array}{l}\text { Cross- } \\
\text { sectional }\end{array}$ & 427 & $\begin{array}{l}215 \\
(50.3 \%)\end{array}$ & $\begin{array}{l}\text { rs } \\
12979860\end{array}$ & $243 / 277$ & $122 / 150$ & 20 \\
\hline $\begin{array}{l}\text { Juliene Antonio } \\
\text { Ramos [19] } \\
2012 \text { Brazil }\end{array}$ & $\begin{array}{l}\text { Cross- } \\
\text { sectional }\end{array}$ & $179 \mathrm{~b}$ & $\begin{array}{l}91 \\
(50.8 \%)\end{array}$ & $\begin{array}{l}\text { rs } \\
12979860\end{array}$ & $36 / 161$ & $16 / 17$ & 21 \\
\hline $\begin{array}{l}\text { Angeles Ruiz- } \\
\text { Extremera [71] } \\
2011 \text { Spain }\end{array}$ & Retrospective & $22 \mathrm{c}$ & $9(40.1 \%)$ & $\begin{array}{l}\text { rs } \\
12979860\end{array}$ & $1 / 8$ & $5 / 7$ & 22 \\
\hline \multicolumn{8}{|c|}{$\begin{array}{l}\text { Abbreviations : HCV, hepatitis C virus; SNP, single-nucleotide polymorphism; n, number; (\%), } \\
\text { (percentage); Event Exposure, the individuals with both chronic hepatitis C \& favorable SNP (rs } \\
12979860 \text { CC); Non Exposure, the individuals with both spontaneous resolution \& \& favorable SNP (rs } \\
12979860 \text { CC); IDst, ID study; NR, not reported; *, the whole of sample size in pregnant women; a, } 2 \\
\text { cases of samples were missed; b, } 1 \text { case of samples was missed c, the analysis for } 7 \text { cases of samples } \\
\text { was not applicable }\end{array}$} \\
\hline
\end{tabular}

\section{Statistical analysis}

Meta-analysis was supposed to be performed on odds ratios for the association of cytokine gene polymorphisms (exposure) and spontaneous recovery (RS) from hepatitis c virus infection (outcome). Because in most of the included studies the reference group in calculation of OR was spontaneous recovery, the ORs and their $95 \% \mathrm{Cl}$ were reversed in the rest of the studies to make the reference group identical. Numerator of the reported prevalence were rs $12979860 \mathrm{CC}$ and its denominator were rs 12979860 CC, CT and TT. (favorable homozygous versus heterozygous plus unfavorable homozygous). Then random effects model was used to combine ORs. Random effects model was preferred over fixed effect 
model because it could be assumed that at least some of the variation among studies are real. This variation among studies, also called heterogeneity, was assessed using Cochran's $Q$ test and the I squared statistic. To find out the study characteristics that could account for the possible heterogeneity, subgroup analysis was performed for country and study type and meta-regression was applied for mean of age and gender proportion. Publication bias was assessed statistically based on Egger's and Begg's tests and visually based on funnel plot. In order to find if one of the studies have a considerable effect on the summary effect influential analysis was performed. In this procedure each study is removed in turn and after which the summary effect is calculated providing the possibility to compare the summary effect with and without that study. All analysis was performed using packages for meta-analysis installed in Stata 14.1. significance level was set at $5 \%$.

\section{Results}

The flowchart of the literature search procedure is illustrated in Fig. 1. According to the search strategy, 545 articles were retrieved from the related databases; and in the study selection step, 22 papers were considered in our meta-analysis (Fig. 1). From the twenty two articles, three studies were performed in Iran, three in Italy, two in Australia, two in France, two in the UK, two in Brazil, one in the USA, one in Mexico, one in Germany, one in Spain, one in Egypt, one in Morocco, one in China and one in Pakistan. All the included studies were English-language articles. The characteristics of each study included in the meta-analysis are shown in Table 1. The results of assessing the risk of bias in the included studies using the Cochrane checklist are presented in Fig. 2 and Table 2.

Figure 2 demonstrates the results of all the included studies based on REM. The summary effect (OR) as 2.75 with $95 \% \mathrm{Cl}$ from 2.23 to 3.38 (P-value $<0.000$ ), shows that the odds of SC from hepatitis C virus infection is 2.75 times higher in those with cytokine gene polymorphisms. In terms of heterogeneity, 12 was $66.5 \%(P=0.00)$ that indicates the presence of some heterogeneity among the results of the included studies, and accordingly, REM was applied to account for this heterogeneity (Fig. 1). However, to deal with heterogeneity subgroup analysis was used for country and study type and meta-regression was applied for the mean of age and gender proportion. Nonetheless, none of them could persuasively account for the observed heterogeneity. Regarding publication bias, there is some asymmetry in the funnel plot presented in Fig. 3. Besides, Egger's test p-value was 0.001 showing the presence of publication bias (Fig. 3). In order to adjust for possible publication, bias trim and fill approach was used which resulted in OR of 2.09 but was not significantly different from 2.74. Besides, to assess the effect of individual studies on the summary effect influential analysis was performed and its output is indicated in Fig. 4. The three horizontal lines indicate the summary effect and its $95 \% \mathrm{Cl}$. Each vertical line shows the summary effect and its $95 \% \mathrm{Cl}$ after elimination of the study specified by its ID in the $x$ axis. The result of the influential analysis shows that the elimination of none of the studies could statistically or clinically change the summary effect. In other words, the summary effect was not sensitive to individual studies.

Association of IL-28 polymorphism and virus genotype In order to investigate the association of rs 12979860 CC and genotype, we compared the prevalence of rs12979860 CC in genotype one versus 
other genotypes all of which were restricted only to SC cases. This comparison was performed through a meta-analysis that pooled the prevalence of rs $12979860 \mathrm{CC}$ over two subgroups genotype one and other. It was found that there was some association between rs $12979860 \mathrm{CC}$ and genotype as the prevalence of rs $12979860 \mathrm{CC}$ was 0.33 with $95 \mathrm{Cl}(0.28-0.38)$ in genotype one and was 0.40 with $95 \mathrm{Cl}(0.34-0.47)$ in other genotypes.

\section{Discussion}

The results of numerous studies indicated that the analysis of genetic polymorphisms can help to understand the mechanism of disease and the differences in the complexity of the disease between individuals [45]. HCV is a serious reason for both acute and chronic hepatitis in infected individuals. It is estimated that the SC of the virus happens in $20 \%$ of patients with acute HCV infection, and liver cirrhosis and hepatocellular carcinoma (HCC) in chronic HCV patients could be an inevitable process [46]. An increasing body of experimental and clinical evidence since 2009 and genome-wide association studies (GWAS) have indicated that polymorphisms close to the IL-28B gene (interferon lambda) are associated with increased rates of SC in studied subjects with chronic HCV infection $[47,48]$. However, in some cases, there are contradictory conclusions, and while some studies have reported significant associations, others didn't find any associations [49-51]. IL-28B similar to other types III IFNs, such as IL-28A and IL-29, shows a strong antiviral activity and induces ISGs [52]. In the present work, we performed a systematic review and meta-analysis to examine the efficacy of a genetic variant (rs12979860) located in a gene (IFN- $\lambda 3$ ) involving in host innate immunity on the HCV SC. Based on our meta-analysis result, rs12979860 SNP exhibited a significant association with HCV SC and sustained virologic response (SVR). The Pooled result of all the included studies indicated a significant association between rs 12979860 CC and SVR in HCV patients treated with PEG IFN-a/RBV. The result indicates that the ORs of SC from HCV infection is 2.75 times higher in those with cytokine gene polymorphisms, $95 \% \mathrm{Cl}$ (2.23 to 3.38). Although the molecular mechanism of the effect of IL-28B gene polymorphism on HCV clearance is unclear, several studies have shown that various factors including viral, host, epidemiological, and environmental factors can be accompanied with HCV clearance $[53,54]$. Preliminary reports evaluating the association between IL28B SNPs and the clearance of HCV have been reported in large groups of patients who are chronically infected with HCV and have been treated with standard antiviral drugs[55,56]. Thomas et al. [54] and Shi et al [21] showed that rs 12979860 SNP firmly augments the probability of HCV clearance among patients from either African or European ancestry. Their result indicated that there was almost a 3-fold greater rate of virus clearance in patients with the rs 12979860 genotype CC versus those with TT or CT. Although, T rs8099917 and C rs12979860, most strongly associated with HCV clearance, they might be affected by the HCV genotype, racial diversity, and population differences. It has been demonstrated that the polymorphism in IL-28B gene appears to be a weaker pretreatment predictor for anti-viral responses in individuals with HCV-2 and HCV-3 than in those with HCV-1 [20]. Hepatitis $\mathrm{C}$ treatment could be affected by several viral factors such as the genotype of the virus, quasi-species, primary load of the virus, and the kinetics of virus $[6,57]$. 
Regarding the existence of different HCV genotypes, patients with HCV that treated with PEG IFN-a/RBV produce a variable SVR and SVR for each genotype differs, so that individuals with genotype 2 have the highest rate of SVR and those with genotypes 1 and 4 have the lowest SVR rate [58]. In our work, virus genotype stratification analyses revealed that there was some association between rs $12979860 \mathrm{CC}$ and genotype as the prevalence of rs $12979860 \mathrm{CC}$ was 0.33 with $95 \mathrm{Cl}(0.28-0.38)$ in genotype one and was 0.40 with $95 \mathrm{Cl}(0.34-0.47)$ in other genotypes. However, the observed association, though consistent with the available literature, was not statistically significant as the two Cls overlapped each other. This could be explained by the low precision of the included studies or their low number. Our work may have some limitations that should be taken into consideration when interpreting the results. In the present study, only published studies have been used, and it is best to include all available individual patient data, such as previously unpublished data. Moreover, other factors besides genetic factors including viral load, patient's physiological and physical characteristics can affect the SC of infection in individuals with chronic HCV that treated with antiviral therapy. Also, due to the small size of the genotypes $2 / 3$ and genotype 4 , it may be argued that our conclusion cannot be generalized, and future researches with a larger number of patients per each group of genotypes $2 / 3$ and genotype 4 and from different ethnic groups need to be studied to confirm the connection with the IL28B polymorphism. Nonetheless, our results suggest that IL28B rs 12979860 CC is a robust predictor of SC in patients with chronic HCV.

\section{Declarations}

\section{Ethics approval}

1-This is an observational study. The Shiraz University of Medical Sciences Research Ethics Committee has confirmed that no ethical approval is required.

2- Compliance with ethical standards

\section{Conflict of interest}

All authors declare they have no conflicts of interest

\section{Funding information}

Shiraz University of Medical Sciences,

Grant/Award Number: 19569

\section{Acknowledgment}

This work was supported by a grant from Shiraz University of Medical Sciences

(No. 15969).

\section{References}


1. 1. Mohamed AA, Elbedewy TA, El-Serafy M, El-Toukhy N, Ahmed W, El Din ZA (2015) Hepatitis C virus: A global view. World journal of hepatology 7 (26):2676

2. 2. Mohd Hanafiah K, Groeger J, Flaxman AD, Wiersma ST (2013) Global epidemiology of hepatitis C virus infection: new estimates of age-specific antibody to HCV seroprevalence. Hepatology 57 (4):1333-1342

3. 3. Petruzziello A, Marigliano S, Loquercio G, Cozzolino A, Cacciapuoti C (2016) Global epidemiology of hepatitis $C$ virus infection: An up-date of the distribution and circulation of hepatitis $C$ virus genotypes. World journal of gastroenterology 22 (34):7824

4. 4. Jiménez-Sousa MA, Fernández-Rodríguez A, Guzmán-Fulgencio $M$, García-Álvarez $M$, Resino $S$ (2013) Meta-analysis: implications of interleukin-28B polymorphisms in spontaneous and treatmentrelated clearance for patients with hepatitis C. BMC medicine 11 (1):6

5. 5. Micallef J, Kaldor J, Dore G (2006) Spontaneous viral clearance following acute hepatitis $C$ infection: a systematic review of longitudinal studies. Journal of viral hepatitis 13 (1):34-41

6. 6. Chuang W-L, Yu M-L (2013) Host factors determining the efficacy of hepatitis $C$ treatment. Journal of gastroenterology 48 (1):22-30

7. 7. Georgel P, Schuster C, Zeisel MB, Stoll-Keller F, Berg T, Bahram S, Baumert TF (2010) Virus-host interactions in hepatitis $C$ virus infection: implications for molecular pathogenesis and antiviral strategies. Trends in molecular medicine 16 (6):277-286

8. 8. Lloyd AR, Jagger E, Post JJ, Crooks LA, Rawlinson WD, Hahn YS, Ffrench RA (2007) Host and viral factors in the immunopathogenesis of primary hepatitis $C$ virus infection. Immunology and cell biology 85 (1):24-32

9. 9. Arends JE, Fransen JH, Hoepelman Al, van Baarle D (2011) Association between IL28B polymorphisms and first-phase viral load decrease in chronic hepatitis $C$ virus-infected patients treated with peginterferon alfa-2b/ribavirin. International journal of antimicrobial agents 38 (6):538-539

10. 10. Mizokami M (2012) Discovery of critical host factor, IL-28B, associated with response to hepatitis C virus treatment. Journal of gastroenterology and hepatology 27 (3):425-429

11. 11. Kim SU, Song KJ, Chang HY, Shin E-C, Park JY, Han K-H, Chon CY, Ahn SH (2013) Association between IL28B polymorphisms and spontaneous clearance of hepatitis B virus infection. PLoS One 8 (7):e69166

12. 12. Marcello T, Grakoui A, Barba-Spaeth G, Machlin ES, Kotenko SV, Macdonald MR, Rice CM (2006) Interferons $\mathrm{a}$ and $\lambda$ inhibit hepatitis $C$ virus replication with distinct signal transduction and gene regulation kinetics. Gastroenterology 131 (6):1887-1898

13. 13. Pagliaccetti NE, Robek MD (2010) Interferon- $\lambda$ in HCV infection and therapy. Viruses 2 (8):15891602

14. 14. Berger CT, Kim AY (2012) IL28B polymorphisms as a pretreatment predictor of response to HCV treatment. Infectious Disease Clinics 26 (4):863-877

15. 15. Neumann $U$ (2011) Impact of IL-28B polymorphism on outcome in patients with hepatitis $C$ after liver transplantation. Expert review of gastroenterology \& hepatology 5 (4):429-431 
16. 16. Sulkowski M, Rodriguez-Torres M, Lawitz E, Shiffman M, Pol S, Herring R, McHutchison J, Pang P, Brainard D, Wyles D (2012) 1421 High Sustained Virologic Response Rate in Treatment-Naive HCV Genotype 1a and 1b Patients Treated for 12 Weeks with an Interferon-Free All-Oral Quad Regimen: Interim Results. Journal of Hepatology 56:S560

17. 17. Chen T-Y, Hsieh Y-S, Wu T-T, Yang S-F, Wu C-J, Tsay GJ, Chiou H-L (2007) Impact of serum levels and gene polymorphism of cytokines on chronic hepatitis C infection. Translational Research 150 (2):116-121

18. 18. Li S, Hu P, Zhang Q-Q, Liu Y-H, Hu H-D, Zhang D-Z, Ren H (2011) Single nucleotide polymorphisms of the IL28B and sustained virologic response of patients with chronic hepatitis C to PEGinterferon/ribavirin therapy: A meta-analysis: Meta-analysis of IL28B. Hepatitis monthly 11 (3):163

19. 19. Ramos JA, Silva R, Hoffmann L, Ramos ALA, Cabello PH, Ürményi TP, Villella-Nogueira CA, LewisXimenez L, Rondinelli EJBrn (2012) Association of IL-10, IL-4, and IL-28B gene polymorphisms with spontaneous clearance of hepatitis $C$ virus in a population from Rio de Janeiro. 5 (1):508

20. 20. Schreiber J, Moreno C, Garcia BG, Louvet A, Trepo E, Henrion J, Thabut D, Mathurin P, Deltenre P (2012) Meta-analysis: the impact of IL 28 B polymorphisms on rapid and sustained virological response in HCV-2 and-3 patients. Alimentary pharmacology \& therapeutics 36 (4):353-362

21. 21. Shi K-Q, Liu W-Y, Lin X-F, Fan Y-C, Chen Y-P, Zheng M-H (2012) Interleukin-28B polymorphisms on the SVR in the treatment of naive chronic hepatitis $C$ with pegylated interferon-a plus ribavirin: A metaanalysis. Gene 507 (1):27-35

22. 22. Hashem M, Jhaveri R, Saleh DaA, Sharaf SA, El-Mougy F, Abdelsalam L, Shardell MD, El-Ghazaly H, El-Kamary SSJCID (2017) Spontaneous viral load decline and subsequent clearance of chronic hepatitis $\mathrm{C}$ virus in postpartum women correlates with favorable interleukin-28B gene allele. 65 (6):999-1005

23. 23. Sarvari J, Mansouri M, Hashempoor T, Hosseini SY, Moattari A, Pirbonyeh N, Dowran R, Moayedi J, Musavi Z, Fattahi M-RJHM (2017) Association of genotype and haplotype of IL-28B Gene with Hepatitis $\mathrm{C}$ infection outcome in iran: Spontaneous clearance versus chronic infection. 17 (5)

24. 24. Falleti E, Bitetto D, Fabris C, Cussigh A, Fornasiere E, Cmet S, Fumolo E, Bignulin S, Fontanini E, Cerutti AJJoci (2011) Role of interleukin 28B rs12979860 C/T polymorphism on the histological outcome of chronic hepatitis C: relationship with gender and viral genotype. 31 (5):891-899

25. 25. Grebely J, Page K, Sacks-Davis R, van der Loeff MS, Rice TM, Bruneau J, Morris MD, Hajarizadeh B, Amin J, Cox ALJH (2014) The effects of female sex, viral genotype, and IL28B genotype on spontaneous clearance of acute hepatitis C virus infection. 59 (1):109-120

26. 26. Carapito R, Poustchi H, Kwemou M, Untrau M, Sharifi A, Merat S, Haj-Sheykholeslami A, Jabbari H, Esmaili S, Michel SJG, Immunity (2015) Polymorphisms in EGFR and IL28B are associated with spontaneous clearance in an HCV-infected Iranian population. 16 (8):514-518

27. 27. Indolfi G, Mangone G, Bartolini E, Nebbia G, Calvo PL, Moriondo M, Tovo P-A, De Martino M, Azzari C, Resti MJPo (2014) Comparative analysis of rs12979860 SNP of the IFNL3 gene in children with hepatitis C and ethnic matched controls using 1000 Genomes Project data. 9 (1):e85899 
28. 28. Knapp S, Warshow U, Ho KA, Hegazy D, Little AM, Fowell A, Alexander G, Thursz M, Cramp M, Khakoo SIJG (2011) A polymorphism in IL28B distinguishes exposed, uninfected individuals from spontaneous resolvers of HCV infection. 141 (1):320-325. e322

29. 29. Ezzikouri S, Alaoui R, Rebbani K, Brahim I, Fakhir F-Z, Nadir S, Diepolder H, Khakoo SI, Thursz M, Benjelloun SJPO (2013) Genetic variation in the interleukin-28B gene is associated with spontaneous clearance and progression of hepatitis C virus in Moroccan patients. 8 (1):e54793

30. 30. Indolfi G, Mangone G, Calvo PL, Bartolini E, Regoli M, Serranti D, Calitri C, Tovo P-A, de Martino M, Azzari CJJopg, nutrition (2014) Interleukin 28B rs12979860 single-nucleotide polymorphism predicts spontaneous clearance of hepatitis $C$ virus in children. 58 (5):666-668

31. 31. Kurbanov F, Abdel-Hamid M, Latanich R, Astemborski J, Mohamed M, Mikhail NM, El-Daly M, ElKafrawy S, Thomas DL, Thio CLJJoID (2011) Genetic polymorphism in IL28B is associated with spontaneous clearance of hepatitis C virus genotype 4 infection in an Egyptian cohort. 204 (9):13911394

32. 32. Knapp S, Zakaria Z, Hashem M, Zaghla H, Khakoo SI, Waked I, Thursz M, Abdelwahab SFJHi (2015) Influence of IFNL3. rs12979860 and IFNL4. ss469415590 polymorphism on clearance of hepatitis $C$ virus infection among Egyptians. 9 (2):251-257

33. 33. Fabrício-Silva GM, Poschetzky BS, de Mello Perez R, dos Santos RC, Cavalini LT, Porto LCJHme, research (2015) Association of cytokine gene polymorphisms with hepatitis $\mathrm{C}$ virus infection in a population from Rio de Janeiro, Brazil. 7:71

34. 34. Shebl FM, Pfeiffer RM, Buckett D, Muchmore B, Chen S, Dotrang M, Prokunina-Olsson L, Edlin BR, O'Brien TRJTJoid (2011) IL28B rs12979860 genotype and spontaneous clearance of hepatitis C virus in a multi-ethnic cohort of injection drug users: evidence for a supra-additive association. 204 (12):1843-1847

35. 35. Sharafi H, Alavian SM, Behnava B, Pouryasin A, Keshvari MJHm (2014) The impact of IFNL4 rs12979860 polymorphism on spontaneous clearance of hepatitis C; a case-control study. 14 (10)

36. 36. Laird ME, Mohsen A, Duffy D, Mamdouh R, LeFouler L, Casrouge A, El-Daly M, Rafik M, AbdelHamid M, Soulier AJJoh (2014) Apolipoprotein H expression is associated with IL28B genotype and viral clearance in hepatitis $C$ virus infection. 61 (4):770-776

37. 37. Nattermann J, Timm J, Nischalke HD, Olbrich A, Michalk M, Tillmann HL, Berg T, Wedemeyer H, Tenckhoff H, Wiese MJJoh (2011) The predictive value of IL28B gene polymorphism for spontaneous clearance in a single source outbreak cohort is limited in patients carrying the CCR5 $\Delta 32$ mutation. 55 (6):1201-1206

38. 38. Spada E, Amoroso P, Taliani G, Zuccaro O, Chiriacò P, Maio P, Maio G, Esposito ML, Mariano C, Rinaldi RJCid (2013) Role of IL28B gene polymorphism and cell-mediated immunity in spontaneous resolution of acute hepatitis C. 57 (6):803-811

39. 39. Wu R-R, Liu F-Q, Zhu S-S, Han JJPJoMS (2014) Association of Hepatitis C Virus Infection and Interleukin-28B Gene Polymorphism in Chinese Children. 30 (3):519 
40. 40. Ruiz-Extremera Á, Muñoz-Gámez JA, Salmerón-Ruiz MA, de Rueda PM, Quiles-Pérez R, GilaMedina A, Casado J, Belén Martín A, Sanjuan-Nuñez L, Carazo AJH (2011) Genetic variation in interleukin 28B with respect to vertical transmission of hepatitis $\mathrm{C}$ virus and spontaneous clearance in HCV-infected children. 53 (6):1830-1838

41. 41. Pedergnana V, Abdel-Hamid M, Guergnon J, Mohsen A, Le Fouler L, Theodorou I, Mohamed MK, Fontanet A, Plancoulaine S, Abel LJPo (2012) Analysis of IL28B variants in an Egyptian population defines the 20 kilobases minimal region involved in spontaneous clearance of hepatitis $C$ virus. 7 (6):e38578

42. 42. Gonzalez-Aldaco K, Rebello Pinho JR, Roman S, Gleyzer K, Fierro NA, Oyakawa L, Ramos-Lopez O, Ferraz Santana RA, Sitnik R, Panduro AJPo (2016) Association with spontaneous hepatitis C viral clearance and genetic differentiation of IL28B/IFNL4 haplotypes in populations from Mexico. 11 (1): $\mathrm{e} 0146258$

43. 43. Hashem M, Zaghla H, Zakaria Z, Allam WR, Sameea EA, Mikhail NN, Sobhy M, Galal IF, Mokhtar Y, Hamdy SJJoMV (2018) High spontaneous clearance of symptomatic iatrogenic acute hepatitis C genotype 4 infection. 90 (12):1841-1847

44. 44. Abdelwahab SF, Zakaria Z, Allam WR, Hamdy S, Mahmoud MA, Sobhy M, Rewisha E, Waked IJAov (2015) Interleukin 28B. rs12979860 genotype does not affect hepatitis C viral load in Egyptians with genotype 4 chronic infection. 160 (11):2833-2837

45. 45. Blazer DG, Hernandez LM (2006) Genes, behavior, and the social environment: Moving beyond the nature/nurture debate. National Academies Press,

46. 46. Cariani E, Roli L, Missale G, Villa E, Ferrari C, Trenti T (2016) Interleukin 28B polymorphisms as predictors of sustained virological response in chronic hepatitis $\mathrm{C}$ : systematic review and metaanalysis. The pharmacogenomics journal 16 (1):18-29

47. 47. Balagopal A, Thomas DL, Thio CL (2010) IL28B and the control of hepatitis C virus infection. Gastroenterology 139 (6):1865-1876

48. 48. Zhang L, Jilg N, Shao R-X, Lin W, Fusco DN, Zhao H, Goto K, Peng LF, Chen W-C, Chung RT (2011) IL28B inhibits hepatitis $\mathrm{C}$ virus replication through the JAK-STAT pathway. Journal of Hepatology 55 (2):289-298

49. 49. Moghaddam A, Melum E, Reinton N, Ring-Larsen H, Verbaan H, Bjøro K, Dalgard O (2011) IL28B genetic variation and treatment response in patients with hepatitis $C$ virus genotype 3 infection. Hepatology 53 (3):746-754

50. 50. Patel K, Lucas JE, Thompson JW, Dubois LG, Tillmann HL, Thompson AJ, Uzarski D, Califf RM, Moseley MA, Ginsburg GS (2011) High predictive accuracy of an unbiased proteomic profile for sustained virologic response in chronic hepatitis $C$ patients. Hepatology 53 (6):1809-1818

51. 51. Venegas M, Villanueva RA, González K, Brahm J (2011) IL28B polymorphisms associated with therapy response in Chilean chronic hepatitis $C$ patients. World Journal of Gastroenterology: WJG 17 (31):3636 
52. 52. Zhou J-h, Wang Y-n, Chang Q-y, Ma P, Hu Y, Cao X (2018) Type III interferons in viral infection and antiviral immunity. Cellular Physiology and Biochemistry 51 (1):173-185

53. 53. Grebely J, Prins M, Hellard M, Cox AL, Osburn WO, Lauer G, Page K, Lloyd AR, Dore GJ (2012) Hepatitis $C$ virus clearance, reinfection, and persistence, with insights from studies of injecting drug users: towards a vaccine. The Lancet infectious diseases 12 (5):408-414

54. 54. Thomas DL, Thio CL, Martin MP, Qi Y, Ge D, O’hUigin C, Kidd J, Kidd K, Khakoo SI, Alexander G (2009) Genetic variation in IL28B and spontaneous clearance of hepatitis C virus. Nature 461 (7265):798-801

55. 55. Suppiah V, Moldovan M, Ahlenstiel G, Berg T, Weltman M, Abate ML, Bassendine M, Spengler U, Dore GJ, Powell E (2009) IL28B is associated with response to chronic hepatitis C interferon-a and ribavirin therapy. Nature genetics 41 (10):1100

56. 56. Tanaka Y, Nishida N, Sugiyama M, Kurosaki M, Matsuura K, Sakamoto N, Nakagawa M, Korenaga M, Hino K, Hige S (2009) Genome-wide association of IL28B with response to pegylated interferon-a and ribavirin therapy for chronic hepatitis C. Nature genetics 41 (10):1105

57. 57. Thio CL (2008) Host genetic factors and antiviral immune responses to hepatitis $C$ virus. Clinics in liver disease 12 (3):713-726

58. 58. Younossi ZM, Baranova A, Afendy A, Collantes R, Stepanova M, Manyam G, Bakshi A, Sigua CL, Chan JP, Iverson AA (2009) Early gene expression profiles of patients with chronic hepatitis $C$ treated with pegylated interferon-alfa and ribavirin. Hepatology 49 (3):763-774

59. 59. Falleti E, Bitetto D, Fabris C, Cussigh A, Fornasiere E, Cmet S, Fumolo E, Bignulin S, Fontanini E, Cerutti A, Minisini R, Pirisi M, Toniutto P (2011) Role of interleukin 28B rs12979860 C/T polymorphism on the histological outcome of chronic hepatitis C: relationship with gender and viral genotype. J Clin Immunol 31 (5):891-899. doi:10.1007/s10875-011-9547-1

60. 60. Carapito R, Poustchi H, Kwemou M, Untrau M, Sharifi AH, Merat S, Haj-Sheykholeslami A, Jabbari H, Esmaili S, Michel S, Toussaint J, Le Gentil M, Ansari-Moghaddam A, Radosavljevic M, Etemadi A, Georgel P, Malekzadeh R, Bahram S (2015) Polymorphisms in EGFR and IL28B are associated with spontaneous clearance in an HCV-infected Iranian population. Genes Immun 16 (8):514-518. doi:10.1038/gene.2015.38

61. 61. Indolfi G, Mangone G, Bartolini E, Nebbia G, Calvo PL, Moriondo M, Tovo PA, de Martino M, Azzari C, Resti M (2014) Comparative analysis of rs12979860 SNP of the IFNL3 gene in children with hepatitis $C$ and ethnic matched controls using 1000 Genomes Project data. PLoS One 9 (1):e85899. doi:10.1371/journal.pone.0085899

62. 62. Gonzalez-Aldaco K, Rebello Pinho JR, Roman S, Gleyzer K, Fierro NA, Oyakawa L, Ramos-Lopez O, Ferraz Santana RA, Sitnik R, Panduro A (2016) Association with Spontaneous Hepatitis C Viral Clearance and Genetic Differentiation of IL28B/IFNL4 Haplotypes in Populations from Mexico. PLoS One 11 (1):e0146258. doi:10.1371/journal.pone.0146258

63. 63. Knapp S, Warshow U, Ho KM, Hegazy D, Little AM, Fowell A, Alexander G, Thursz M, Cramp M, Khakoo SI (2011) A polymorphism in IL28B distinguishes exposed, uninfected individuals from 
spontaneous resolvers of HCV infection. Gastroenterology 141 (1):320-325, 325.e321-322. doi:10.1053/j.gastro.2011.04.005

64. 64. Indolfi G, Mangone G, Calvo PL, Bartolini E, Regoli M, Serranti D, Calitri C, Tovo PA, de Martino M, Azzari C, Resti M (2014) Interleukin 28B rs12979860 single-nucleotide polymorphism predicts spontaneous clearance of hepatitis C virus in children. J Pediatr Gastroenterol Nutr 58 (5):666-668. doi:10.1097/mpg.0000000000000275

65. 65. Knapp S, Zakaria Z, Hashem M, Zaghla H, Khakoo SI, Waked I, Thursz M, Abdelwahab SF (2015) Influence of IFNL3.rs12979860 and IFNL4.ss469415590 polymorphism on clearance of hepatitis C virus infection among Egyptians. Hepatol Int 9 (2):251-257. doi:10.1007/s12072-015-9619-z

66. 66. Fabricio-Silva GM, Poschetzky BS, de Mello Perez R, Dos Santos RC, Cavalini LT, Porto LC (2015) Association of cytokine gene polymorphisms with hepatitis $C$ virus infection in a population from Rio de Janeiro, Brazil. Hepat Med 7:71-79. doi:10.2147/hmer.S89447

67. 67. Laird ME, Mohsen A, Duffy D, Mamdouh R, LeFouler L, Casrouge A, El-Daly M, Rafik M, AbdelHamid M, Soulier A, Pawlotsky JM, Hezode C, Rosa I, Renard P, Mohamed MK, Bonnard P, Izopet J, Mallet V, Pol S, Albert ML, Fontanet A (2014) Apolipoprotein H expression is associated with IL28B genotype and viral clearance in hepatitis C virus infection. J Hepatol 61 (4):770-776. doi:10.1016/j.jhep.2014.05.040

68. 68. Nattermann J, Timm J, Nischalke HD, Olbrich A, Michalk M, Tillmann HL, Berg T, Wedemeyer H, Tenckhoff H, Wiese M, Kullig U, Gobel U, Capka E, Schiefke I, Guthof W, Grungreiff K, Konig I, Roggendorf M, Sauerbruch T, Spengler U (2011) The predictive value of IL28B gene polymorphism for spontaneous clearance in a single source outbreak cohort is limited in patients carrying the CCR5Delta32 mutation. J Hepatol 55 (6):1201-1206. doi:10.1016/j.jhep.2011.03.011

69. 69. Spada E, Amoroso P, Taliani G, Zuccaro O, Chiriaco P, Maio P, Maio G, Esposito ML, Mariano C, Rinaldi R, Bellissima P, Tosti ME, Del Porto P, Francavilla R, Mellace V, Garbuglia AR, Folgori A, Mele A (2013) Role of IL28B gene polymorphism and cell-mediated immunity in spontaneous resolution of acute hepatitis C. Clin Infect Dis 57 (6):803-811. doi:10.1093/cid/cit402

70. 70. Wu RR, Liu FQ, Zhu SS, Han J (2014) Association of Hepatitis C Virus Infection and Interleukin-28B Gene Polymorphism in Chinese Children. Pak J Med Sci 30 (3):519-524. doi:10.12669/pjms.303.4267

71. 71. Ruiz-Extremera A, Munoz-Gamez JA, Salmeron-Ruiz MA, de Rueda PM, Quiles-Perez R, Gila-Medina A, Casado J, Belen Martin A, Sanjuan-Nunez L, Carazo A, Pavon EJ, Ocete-Hita E, Leon J, Salmeron J (2011) Genetic variation in interleukin 28B with respect to vertical transmission of hepatitis $C$ virus and spontaneous clearance in HCV-infected children. Hepatology 53 (6):1830-1838. doi:10.1002/hep.24298

\section{Table}

Table 2 is not available with this version

\section{Figures}




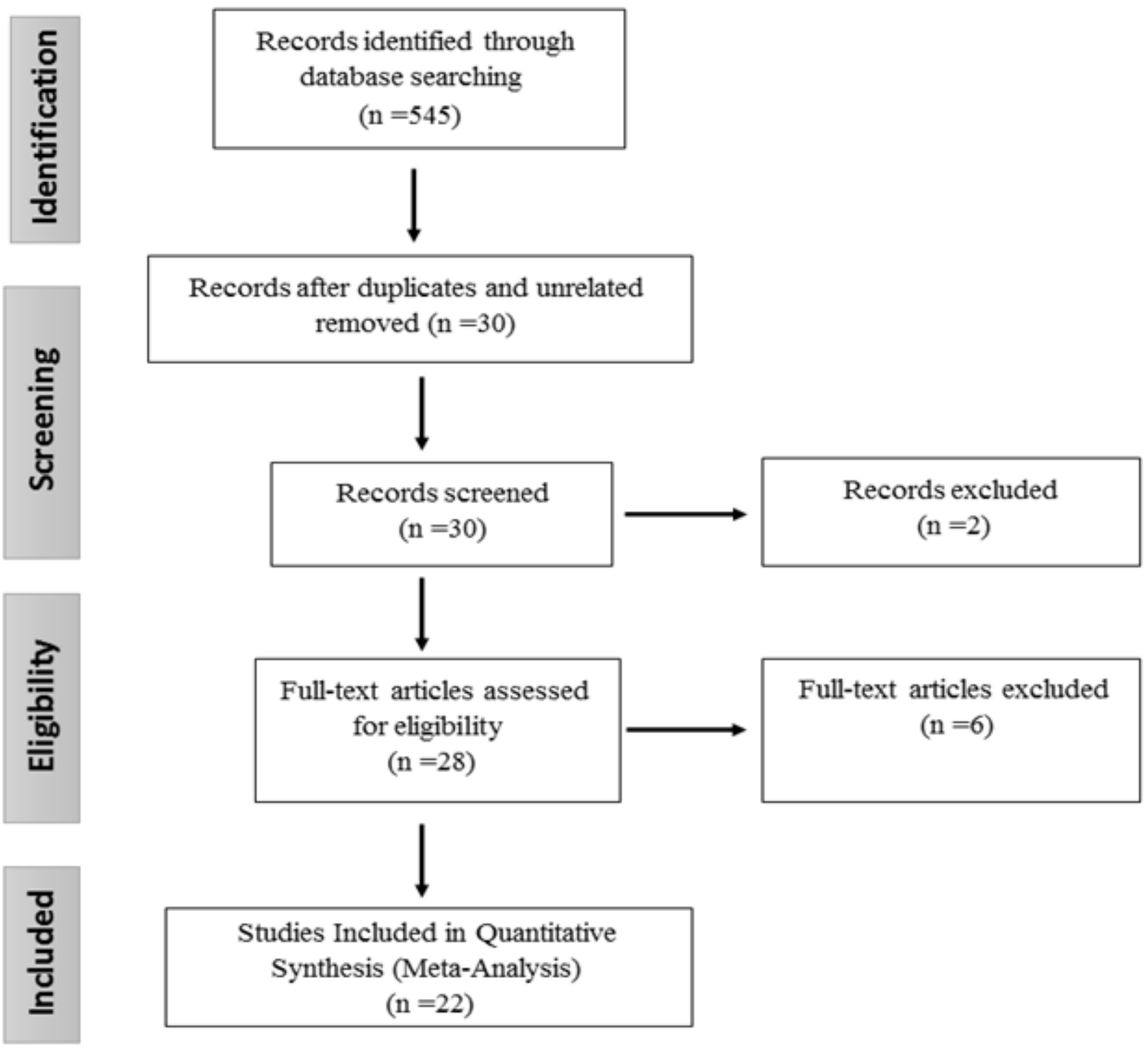

Figure 1

PRISMA Flowchart of the study selection process 


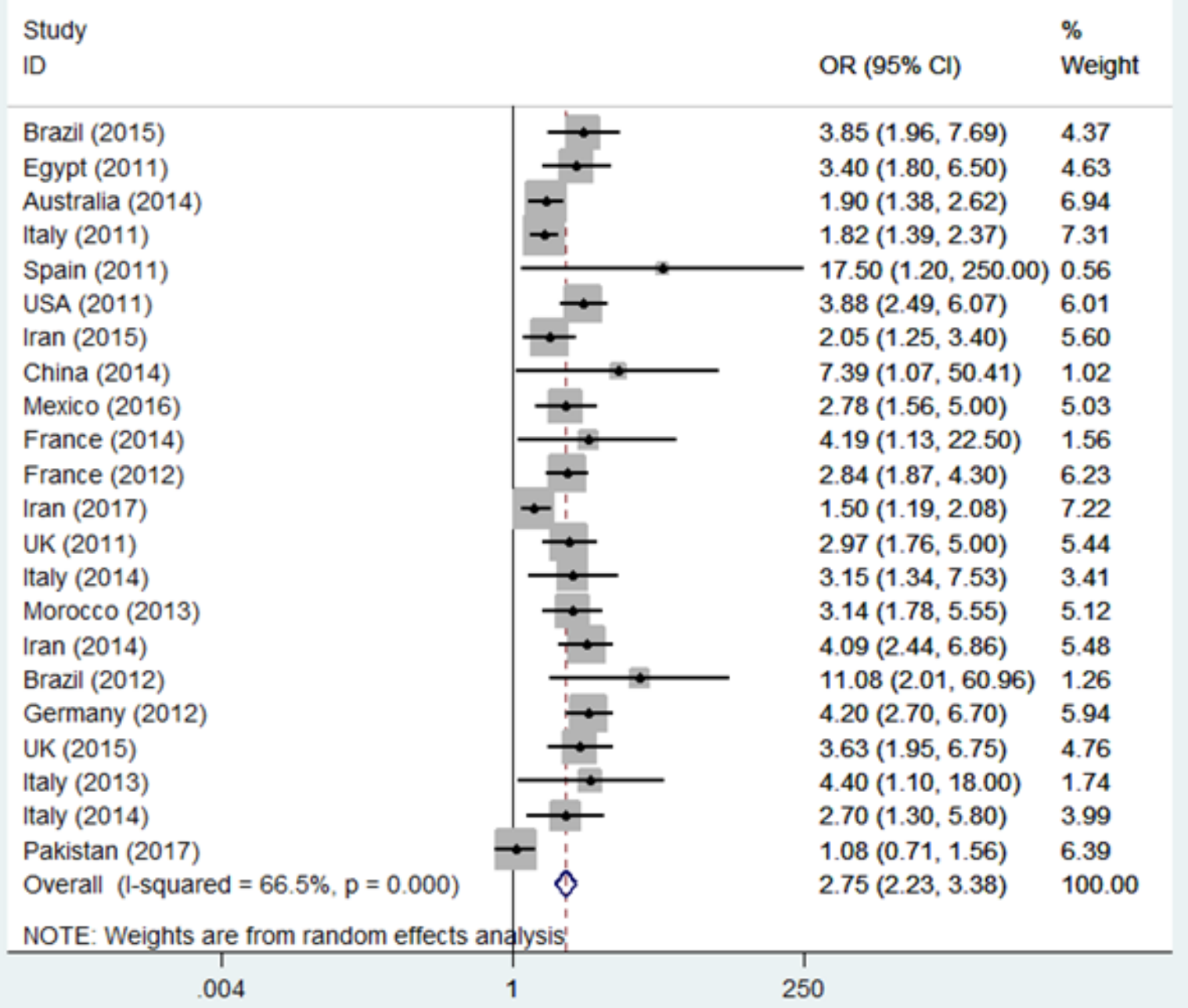

\section{Figure 2}

Forest plot for Odds Ratio for association between cytokine gene polymorphisms and spontaneous recovery (RS) from hepatitis c virus infection. Each square $(\boldsymbol{\square})$ and its horizontal line, respectively, represent the OR and its $95 \% \mathrm{Cl}$ for each individual study (the size of the grey square corresponds to the weight of that study in the meta-analysis); the diamond and its horizontal diagonal $(\diamond)$ show the combined overall OR and its $95 \% \mathrm{Cl}$, respectively. 


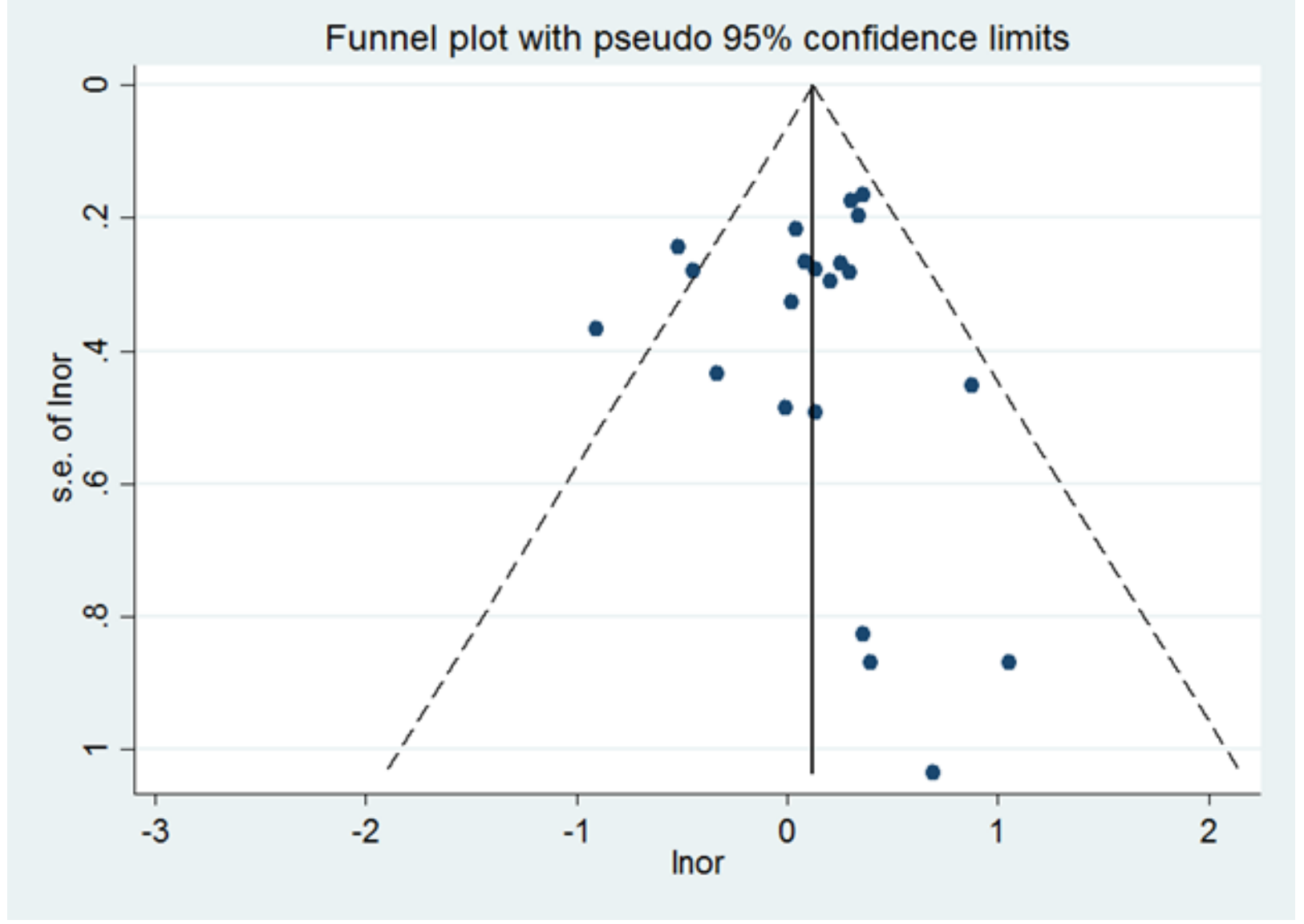

Figure 3

Funnel plot for Odds Ratio for association between cytokine gene polymorphisms and spontaneous recovery (RS) from hepatitis c virus infection. 


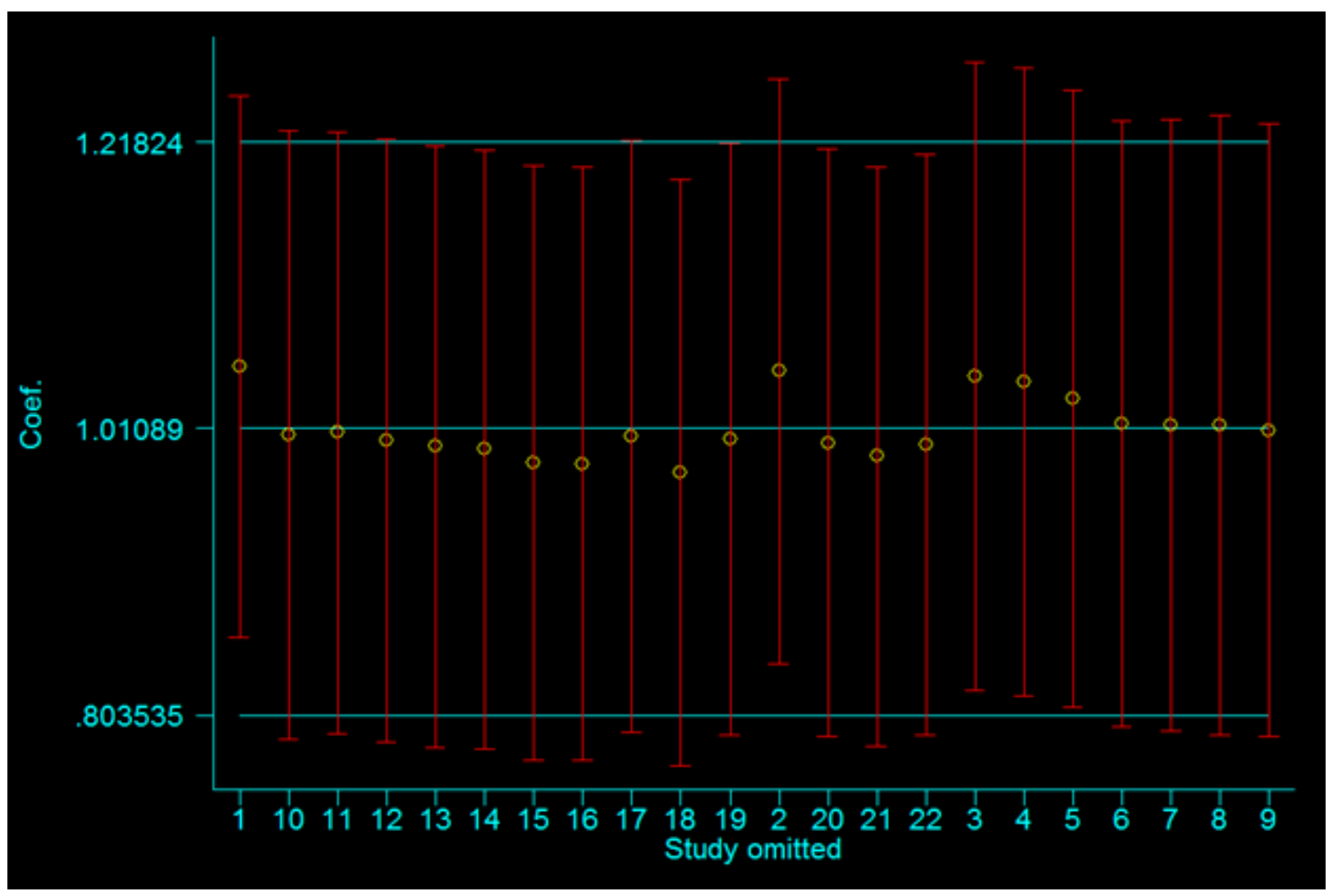

\section{Figure 4}

Plot for assessing the effect of individual studies on the summary effect. The three horizontal lines indicate the summary effect and its $95 \% \mathrm{Cl}$. Each vertical line shows the summary effect and its $95 \% \mathrm{Cl}$ after elimination of the study specified by its ID in the $x$ axis. The scale is natural logarit 